\title{
Relation between Upwelling Intensity and the Variability of Physical and Chemical Parameters in the Southern Benguela Upwelling System
}

\author{
Hassan Ebrahiem Ismail, ${ }^{1}$ Johannes Jacobus Agenbag, ${ }^{1}$ \\ Stephanie de Villiers, ${ }^{1}$ and Bhekumusa Jabulani Ximba ${ }^{2}$ \\ ${ }^{1}$ Department of Environmental Affairs, Oceans and Coasts, Private Bag Box X2, Cape Town 8012, South Africa \\ ${ }^{2}$ Cape Peninsula University of Technology, P.O. Box 1906, Bellville 7535, South Africa
}

Correspondence should be addressed to Hassan Ebrahiem Ismail; ismailhe@gmail.com

Received 13 November 2014; Revised 29 December 2014; Accepted 31 December 2014

Academic Editor: Swadhin Behera

Copyright (c) 2015 Hassan Ebrahiem Ismail et al. This is an open access article distributed under the Creative Commons Attribution License, which permits unrestricted use, distribution, and reproduction in any medium, provided the original work is properly cited.

\begin{abstract}
The extent to which wind-driven seasonal upwelling cycles manifest in surface ocean temperature and nutrient variability along a monitoring line in the Southern Benguela upwelling system was investigated. Monitoring conducted monthly over a six-year period shows that surface temperature and nutrient concentrations exhibit very poor seasonality and weak correlation with the upwelling index. This is, despite clear evidence for spatial inshore-offshore gradients in temperature, nutrients, and chlorophyll, consistent with an upwelling regime. The upper ocean temperature gradient shows a much better correspondence to the upwelling index but at the same time demonstrates that surface heating, and not vertical mixing related to upwelling, controls the upper ocean temperature gradient. The results suggest that remote sensing techniques would be inadequate tools to monitor upwelling events in the Southern Benguela. Also, the incidence of phytoplankton blooms is more likely triggered by stratified conditions associated with surface heating than relaxation of upwelling winds.
\end{abstract}

\section{Introduction}

The Benguela upwelling system stretches from South Africa to Angola and is one of the ocean's four large and most productive eastern boundary upwelling areas [1-3]. It is bound at both the equatorward and poleward ends by warm water regimes, notably the Angola-Benguela Front in the north and the Agulhas Current retroflection area in the south [4]. Eastern boundary currents like the Benguela are driven by equatorward alongshore winds, which also force offshore Ekman transport in the surface boundary layer. Along the coast, this divergence results in the upwelling of cold, nutrient-rich water into the euphotic zone. A wind-driven equatorward frontal jet typically forms a boundary between the open ocean and the upwelled water, with mass balance being provided by a poleward undercurrent at depth. The enrichment of surface water inshore of the front supports high productivity and often a high frequency of harmful algal blooms. A global increase in the incidence of such blooms [5], and the role of productive upwelling areas as global carbon sinks have renewed interest in understanding upwelling processes and the possible role of global change as a driving factor behind change in upwelling dynamics. Of particular interest is the application of satellite oceanography to detect upwelling events, in order to improve spatial and temporal data coverage.

St. Helena Bay, located at the southern end of the Benguela Upwelling system, is the best studied and one of the most productive areas in this system [6]. Upwelling plumes of cold nutrient-rich South Atlantic Central Water (SACW) are characterised by consistent temperature and salinity ( $\mathrm{ca}$ $10^{\circ} \mathrm{C}$ and $34.80 \mathrm{PSU}$ ) [3, 7-9]. Offshore transport in a northwesterly direction eventually causes mixing with or sinking below the warm, high salinity oceanic water $\left(\mathrm{ca} 20^{\circ} \mathrm{C}\right.$ and $35.5 \mathrm{PSU})$ at a convergence front $[10,11]$. In the summer (Dec.-Feb.), the subthermocline waters in the southern Benguela are ventilated by the ocean-shelf exchange of aerated 


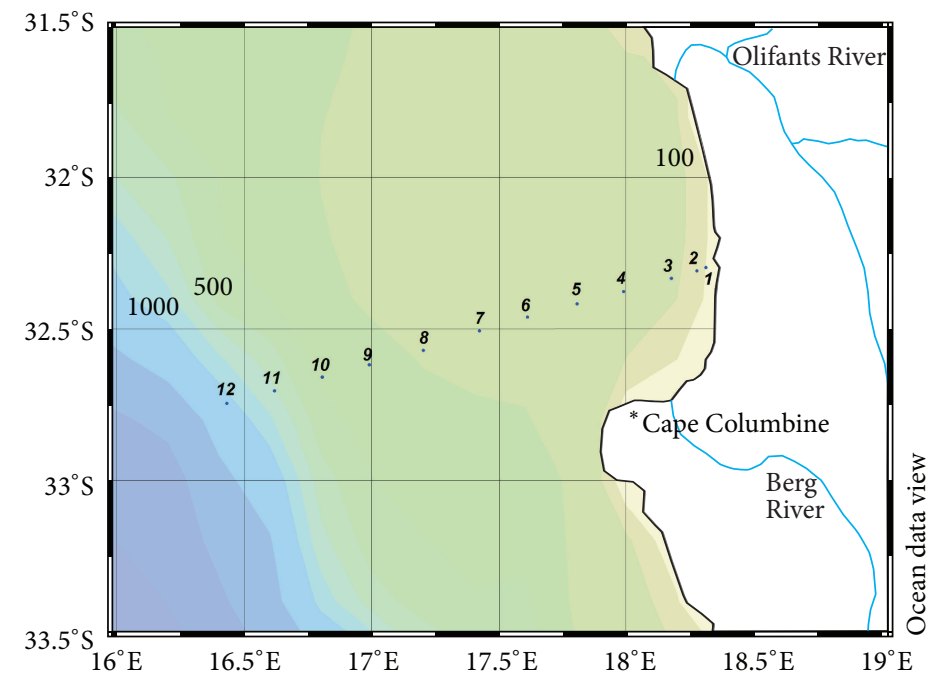

FIGURE 1: The SHBML station positions superimposed on bathymetry. Shallow depths are shown in green and deeper depths in blue tones.

SACW at Cape Columbine and Cape Peninsula at the southern boundary [12]. In the winter (June-August), there is a disruption of the thermocline and a complete reaeration of the water column. St. Helena Bay is also a part of the Benguela Upwelling system that is characterised by expansive red tides and with significant variability spatially and temporarily. Red tides typically develop in response to upwelling relaxation and are characterised by a phytoplankton community shift from diatoms to dinoflagellates.

This study applies data collected monthly over a 6-year period along the almost $200 \mathrm{~km}$ long St. Helena Bay Monitoring Line (SHBML) to investigate covariation between an upwelling index calculated from nearby wind records and physical and chemical properties along the transect. The extent to which the well-documented seasonal upwelling cycles is manifested at the surface along an inshore-offshore was investigated in the context of implications for the validity of remote sensing [13] as a monitoring tool in this ocean area and to improve understanding of the physical drivers of biological processes in St. Helena Bay.

\section{Methods}

2.1. Study Area. The study area is the St. Helena Bay Monitoring Line (SHBML) in the Southern Benguela, along the west coast of South Africa (Figure 1, Table 1). Stations 1 to 12 have bottom depths of 27 to $1396 \mathrm{~m}$, respectively, and are located at distances ranging from 3 to $191 \mathrm{~km}$ offshore (Table 1). The Berg River discharges into St. Helena Bay at Veldrift (Figure 1) and drains a catchment dominated by agriculture, wineries, canneries, and textile milling [14, 15]. Monthly cruises on the research vessels RV Africana, RV Algoa, and RV Ellen Khuzwayo were conducted along the SHBML from January 2004 to December 2009. The SHBML is typically sampled only once during the two-month long October/ November pelagic spawner biomass survey. Upper ocean profiles for temperature, salinity, and chlorophyll- $a$ (Chl-a)
TABLE 1: St. Helena Bay Monitoring Line sampling station details.

\begin{tabular}{ccccc}
\hline $\begin{array}{c}\text { Station } \\
\text { number }\end{array}$ & \multicolumn{2}{c}{ Latitude Longitude } & $\begin{array}{c}\text { Bottom depth } \\
(\mathrm{m})\end{array}$ & $\begin{array}{c}\text { Distance from } \\
\text { coast }(\mathrm{km})\end{array}$ \\
\hline 1 & -32.299 & 18.302 & 27 & 3 \\
2 & -32.310 & 18.276 & 30 & 7 \\
3 & -32.330 & 18.177 & 76 & 17 \\
4 & -32.373 & 17.991 & 104 & 35 \\
5 & -32.413 & 17.808 & 150 & 53 \\
6 & -32.461 & 17.609 & 189 & 73 \\
7 & -32.505 & 17.422 & 235 & 92 \\
8 & -32.570 & 17.204 & 283 & 115 \\
9 & -32.604 & 16.986 & 311 & 134 \\
10 & -32.653 & 16.808 & 386 & 153 \\
11 & -32.699 & 16.620 & 564 & 172 \\
12 & -32.745 & 16.435 & 1396 & 191 \\
\hline
\end{tabular}

and concentrations of dissolved inorganic nutrients (nitrate, phosphate, and silicate) were obtained, for evaluation in conjunction with a series of monthly Ekman upwelling estimates calculated from geostrophic wind data, obtained from the nearby Cape Columbine [6] (Figure 1). The periodicity of the $\mathrm{S}-\mathrm{N}$ wind component of Cape Columbine was produced by the reanalysis cooperative research project between the USA's NOAA National Center for Environmental Prediction (NCEP) and the National Science Foundation's National Center for Atmospheric Research (NCAR) and consists of four-times-daily (0:00, 06:00, 12:00, and 18:00 GMT) wind components on a $2.5^{\circ}$ latitude $\times 2.5^{\circ}$ longitude grid, covering the period January 1948-present [16], downloaded from $\mathrm{ftp}: / / \mathrm{ftp} . \mathrm{cdc}$.noaa.gov/pub/Datasets/ncep.reanalysis/surface.

2.2. Water Sampling and Analysis. Water samples were collected at the near surface (approximately 3 to $5 \mathrm{~m}$ depth) and deeper depths to within $5 \mathrm{~m}$ from the ocean seabed. Physical 


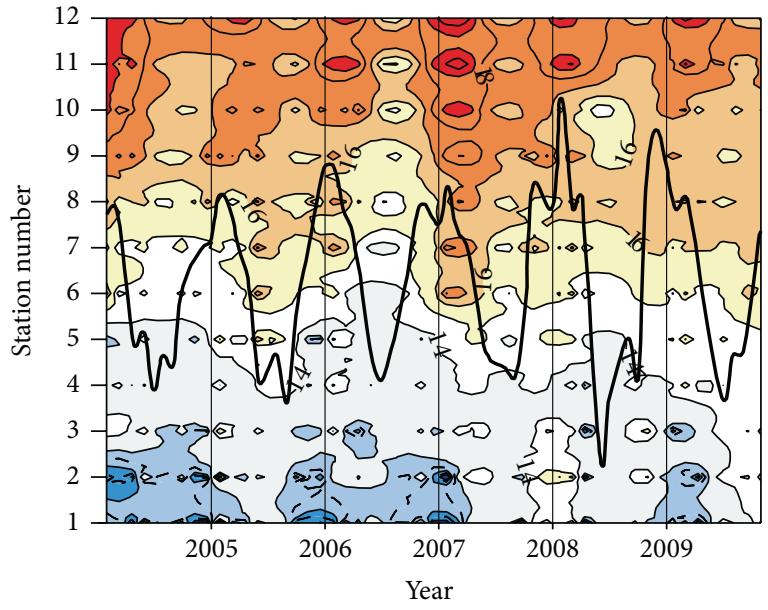

(a) Temperature $\left({ }^{\circ} \mathrm{C}\right)$ near surface

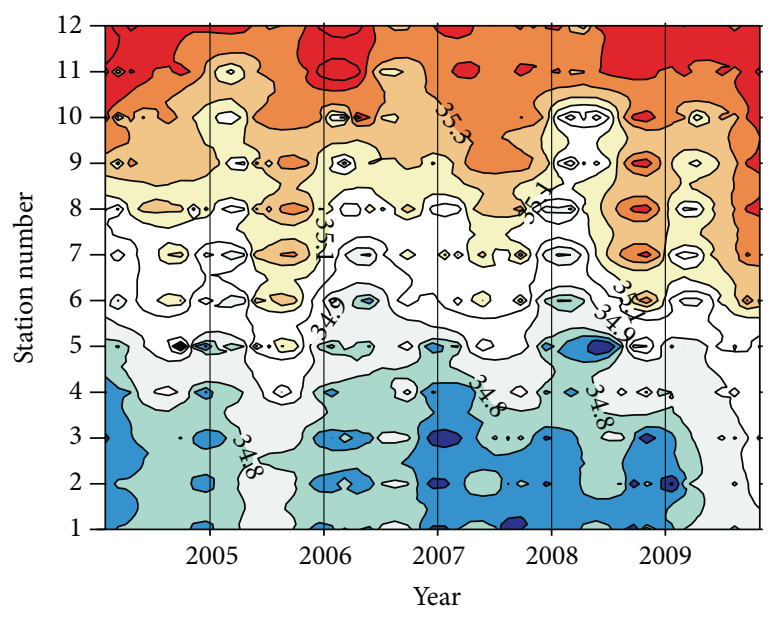

(c) Salinity (PSU) near surface

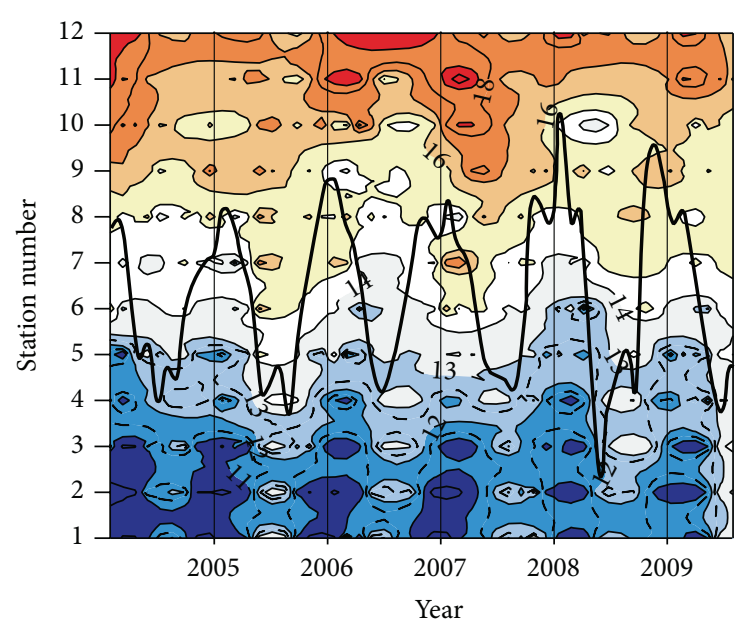

(b) Temperature $\left({ }^{\circ} \mathrm{C}\right)$ at $20 \mathrm{~m}$ depth

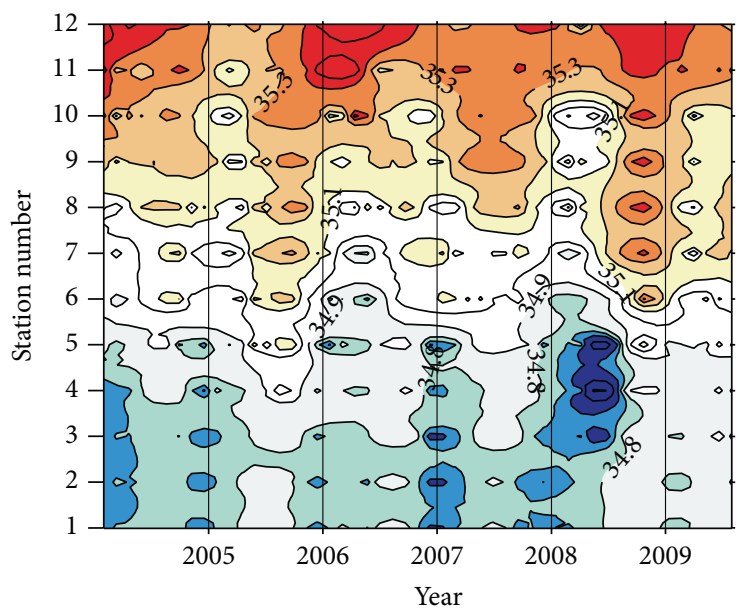

(d) Salinity (PSU) at $20 \mathrm{~m}$ depth

FIGURE 2: Inshore-offshore near-surface ( $\mathrm{a}$ and c) and $20 \mathrm{~m}$ depth (b and d) variability over time for temperature (a and b) and salinity ( $\mathrm{c}$ and d). The thick black line represents the upwelling index (UI). Temperature $\left({ }^{\circ} \mathrm{C}\right)$ and salinity (PSU) values are indicated as labels on respective isobars. The temperature ranged between $<11^{\circ} \mathrm{C}$ (dark blue) and $>18^{\circ} \mathrm{C}$ (red). Salinity ranged between $<34.7$ PSU (dark blue) and $>35.4$ (red).

parameters were measured in situ using a Sea-Bird Electronics SBE 911 plus CTD (conductivity, temperature, and depth) sensor as well as fluorescence sensor. Water temperature was measured to an accuracy of $\pm 0.001^{\circ} \mathrm{C}$. The temperature gradient was used to indicate the presence or absence of a thermocline. Salinity was computed from CTD data in practical salinity units (PSUs) and calibrated using discrete samples (accuracy 0.0003 Siemens/meter).

Water samples for the study of dissolved inorganic nutrients were stored in acid-washed polyethylene bottles with pressure caps and kept frozen at $-80^{\circ} \mathrm{C}$ until analysis ashore. No samples were kept frozen for longer than 3 months before analysis. Dissolved nitrate $\left(\mathrm{NO}_{3}{ }^{-}\right)$, phosphate $\left(\mathrm{PO}_{4}{ }^{3-}\right)$, and silicates were determined according to the methods described by [17]. An Astoria Analyzer Series 300 expanded to four channels was used to perform the nutrient analysis.

Samples for Chl- $a$ analysis were taken at four depths (near-surface, above the fluorescence maximum (F-max), Fmax, and below the F-max). Subsamples $(200 \mathrm{~mL}$ ) of seawater for Chl- $a$ analysis were collected in prerinsed plastic measuring cylinders. Samples were filtered under vacuum onto $25 \mathrm{~mm}$ Whatman GF/F glass fibre filter papers [18]. The filter papers were frozen in aluminium foil pouches for analysis ashore. Chl- $a$ was measured fluorometrically on a Turner Designs 10-AU fluorometer after extraction in $90 \%$ acetone [19]. The fluorometer was calibrated with Chl- $a$ standard (Sigma Chemical Co., USA) in $90 \%$ acetone solution with a GBC Cintra 404 spectrophotometer and an extraction coefficient of $87.67 \mathrm{Lg}^{-1} \mathrm{~cm}^{-1}$.

\section{Results and Discussion}

3.1. Relationship between the Upwelling Index (UI) and SeaSurface Temperature and Salinity. Temperature and salinity variations at the near-surface (Figures 2(a) and 2(c)) and $20 \mathrm{~m}$ depth (Figures 2(b) and 2(d)) for the period 2004 to 2009, at stations 1 (inshore) to 12 (offshore), were evaluated in the context of an upwelling index calculated from geostrophic 


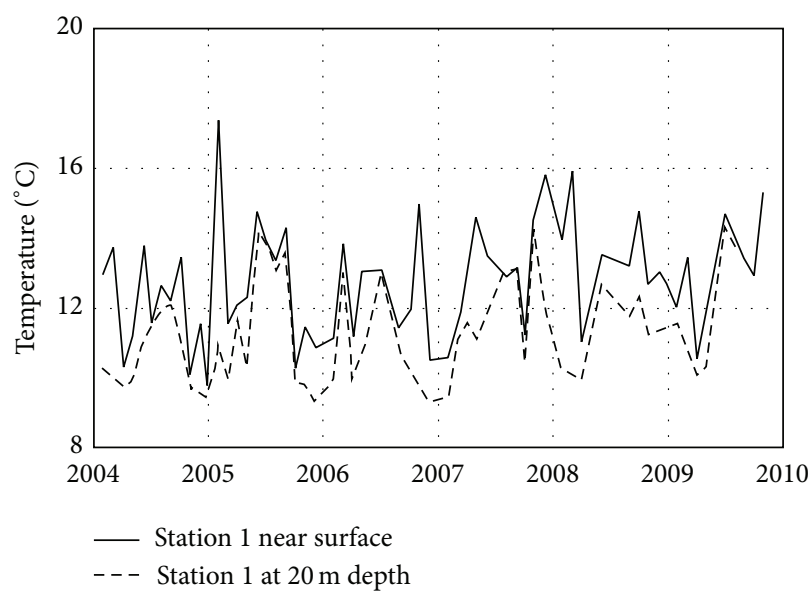

(a)

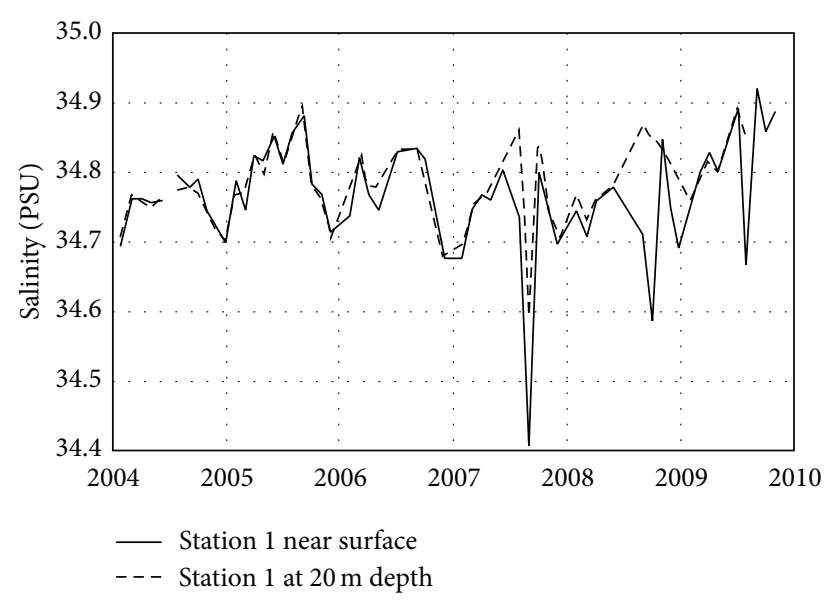

(b)

Figure 3: Temporal changes in (a) temperature and (b) salinity at station 1, near surface and at $20 \mathrm{~m}$ depth.

wind data (black line in Figures 2(a) and 2(b)). The upwelling index (UI) starts to increase in late winter (Aug.), in response to increased south-easterly trade winds, which cause surface Ekman transport in a northwesterly direction and coastal upwelling. The productivity stimulated by the increased availability of nutrients that result from this upwelling is what makes St. Helena Bay one of the most productive areas in the Southern Benguela Upwelling system. As the wind regime changes over from summer (Dec.-Feb.) south-easterlies to predominantly westerly winds in winter (June-Aug.), a relative brief period of downwelling occurs.

On a shelf-wide scale, clear gradients in temperature and salinity are evident, with both parameters increasing with distance offshore. Temperature increases from as low as $9.8^{\circ} \mathrm{C}$ at the coast ( $3 \mathrm{~km}$ offshore) to almost $22^{\circ} \mathrm{C}$ offshore $(191 \mathrm{~km}$ from coast) at the near surface and from 9.34 to $20.61^{\circ} \mathrm{C}$ at $20 \mathrm{~m}$ depth (Figures 2(a) and 2(b)). Salinity values increase from 34.41 at the coast to 35.60 PSU offshore at the near surface and from 34.68 to $35.60 \mathrm{PSU}$ at $20 \mathrm{~m}$ depth (Figures 2(c) and 2(d)). At first glance, it appears that near-surface temperature in St. Helena Bay exhibits seasonal variability, with winter (June-August) temperature 2 to $3^{\circ} \mathrm{C}$ warmer than that observed during the spring (Sept.-Nov.) to late summer (Feb) upwelling season at both the inshore and offshore stations (Figures 2(a) and 2(b)). Closer inspection of the nearsurface data at the more frequently sampled inshore stations, however, reveals that every year contains exceptions to this generalized seasonal trend (Figure 3(a)): there were warm water events outside the "regular" winter (June-August) period during late summer (Feb.) in 2004, summer (Dec.Feb.) in 2005, late summer (Feb.) and spring (Sept.-Nov.) in 2006, late spring (Nov.) in 2007, summer (Dec.-Feb.) in 2008, and late summer (Feb.) and spring (Sept.-Nov.) in 2009. These warm water events are usually, but not always, also observed at $20 \mathrm{~m}$ depth (Figure 3(a)).

Linear regression coefficients between temperature and the upwelling index, which has a very well defined seasonal profile (black line in Figures 2(a) and 2(b)), confirm the poor seasonality visually evident in the near-surface temperature data (Table 2). The expected trend is for surface temperature to decrease in response to upwelling (more positive UI values) and for this to be more pronounced closer to shore, where divergence is more likely to occur. However, near-surface temperature is observed to be very poorly correlated with the UI at the surface (approximately 3 to $5 \mathrm{~m}$ depth), except at the furthest offshore stations (11 and 12), where a weak positive correlation with the UI is observed. At $20 \mathrm{~m}$ depth the expected negative relationship between temperature and the UI is evident at stations 1 to 5 (inshore stations), with again a positive relationship with the UI manifesting at the offshore stations (11 and 12), with the latter slightly weaker than the correlation at the near surface.

There is a more pronounced relationship between the upwelling index and near-surface salinity at the inshore stations than observed for temperature (Table 2, Figures 2(c) and $2(\mathrm{~d})$ ). The data suggests a trend of decreasing salinity values at times of upwelling, at both the near-surface and $20 \mathrm{~m}$ depth, slightly better expressed at $20 \mathrm{~m}$ depth. Seasonal variations in salinity are well-defined from 2004 to 2006 (Figure 3(b)). In 2007, however, the seasonal profile is disrupted by the intrusion of a water mass with typical wintertime (June-August) temperature $\left(13.16^{\circ} \mathrm{C}\right)$ but much lower salinity (34.41 PSU) values than is the norm in July (Figure 3 ), followed by a return to more typical upwelling conditions the following month, that is, colder $\left(11.24^{\circ} \mathrm{C}\right)$ more saline (34.80 PSU) water. Similar but less pronounced intrusions of water masses with lower salinities than normally observed in winter (June-August) disrupt the seasonal salinity profiles in 2008 and 2009 (Figure 3(b)). These fresher-water intrusions are also much more evident at near-surface sampling depths than at $20 \mathrm{~m}$ depth and in 2008 , for example, it is only evident at the near surface.

3.2. Relationship between the UI and Surface Ocean Nutrient and Chlorophyll-a Concentrations. Near-surface ocean distribution patterns for nutrients exhibit across-shelf gradients, 
TABLE 2: Linear regression coefficients (slopes) for physical and chemical variables as a function of the upwelling index at the surface (3 to $5 \mathrm{~m}$ ) and at $20 \mathrm{~m}$ sampling depths, for stations 1 to 12 . Bold values indicate slopes that are significant at $P<0.01$.

\begin{tabular}{|c|c|c|c|c|c|c|c|}
\hline & TEMP & SALINITY & $\mathrm{O}_{2}$ & $\mathrm{NO}_{3}^{-}$ & $\mathrm{PO}_{4}^{3-}$ & $\mathrm{Si}$ & Chl-A \\
\hline 3-5 m @St \# 1 & -0.0031 & -0.0002 & -0.0072 & 0.0215 & 0.0039 & 0.0457 & 0.0328 \\
\hline 2 & -0.0012 & -0.0004 & -0.0028 & 0.0134 & 0.0067 & 0.0632 & 0.0139 \\
\hline 3 & 0.0008 & -0.0007 & 0.0017 & -0.0106 & 0.0034 & 0.0353 & 0.0308 \\
\hline 4 & -0.0002 & -0.0009 & 0.0028 & -0.0098 & 0.0014 & -0.0108 & 0.0301 \\
\hline 5 & -0.0003 & -0.0014 & 0.0031 & -0.0098 & 0.0007 & -0.0153 & 0.0488 \\
\hline 6 & 0.0013 & -0.0017 & 0.0038 & -0.0104 & -0.0002 & -0.0149 & 0.0307 \\
\hline 7 & 0.0029 & -0.0016 & 0.0024 & -0.0148 & -0.0011 & -0.0245 & 0.0285 \\
\hline 8 & 0.0029 & -0.0017 & 0.0024 & -0.0094 & -0.0022 & -0.0214 & 0.0251 \\
\hline 9 & 0.0064 & -0.0009 & -0.0009 & -0.0016 & -0.0011 & -0.0139 & 0.0116 \\
\hline 10 & 0.0068 & -0.0011 & -0.0004 & -0.0056 & -0.0011 & -0.0159 & 0.0158 \\
\hline 11 & 0.0141 & 0.0000 & -0.0019 & -0.0103 & -0.0023 & -0.0151 & 0.0057 \\
\hline 12 & 0.0158 & 0.0002 & -0.0039 & -0.0064 & -0.0017 & -0.0097 & -0.0016 \\
\hline $20 \mathrm{~m} @$ St \# 1 & -0.0169 & -0.0005 & -0.0189 & 0.0581 & 0.0064 & 0.0624 & 0.0233 \\
\hline 2 & -0.0197 & -0.0005 & -0.0230 & 0.0783 & 0.0099 & 0.1011 & 0.0306 \\
\hline 3 & -0.0162 & -0.0007 & -0.0166 & 0.0714 & 0.0077 & 0.0772 & 0.0437 \\
\hline 4 & -0.0167 & -0.0009 & -0.0098 & 0.0629 & 0.0048 & 0.0099 & 0.0454 \\
\hline 5 & -0.0142 & -0.0017 & -0.0088 & 0.0379 & 0.0038 & -0.0007 & 0.0309 \\
\hline 6 & -0.0071 & -0.0013 & -0.0033 & 0.0273 & 0.0021 & 0.0069 & 0.0248 \\
\hline 7 & -0.0040 & -0.0015 & -0.0031 & 0.0155 & 0.0016 & -0.0079 & 0.0349 \\
\hline 8 & -0.0063 & -0.0016 & -0.0032 & -0.0007 & -0.0001 & -0.0168 & 0.0248 \\
\hline 9 & 0.0011 & -0.0009 & -0.0020 & -0.0082 & 0.0004 & -0.0120 & 0.0317 \\
\hline 10 & -0.0016 & -0.0015 & -0.0015 & 0.0105 & 0.0001 & -0.0135 & 0.0142 \\
\hline 11 & 0.0153 & 0.0002 & -0.0028 & -0.0093 & 0.0004 & -0.0213 & 0.0029 \\
\hline 12 & 0.0129 & 0.0000 & -0.0032 & -0.0097 & -0.0019 & -0.0072 & 0.0022 \\
\hline
\end{tabular}

from high values along the coast (up to $26.5 \mu \mathrm{mol} / \mathrm{L}$ for $\mathrm{NO}_{3}{ }^{-}$, $4.16 \mu \mathrm{mol} / \mathrm{L}$ for $\mathrm{PO}_{4}{ }^{3-}$, and $46.8 \mu \mathrm{mol} / \mathrm{L}$ for $\mathrm{Si}$ ) to offshore near-surface values that are typically lower by a factor of 10 as expected in a coastal upwelling area (shown for $\mathrm{PO}_{4}{ }^{3-}$ in Figures 4(a) and 4(b)). This inshore-offshore gradient in nutrient availability is reflected in higher inshore Chl- $a$ levels (above $40 \mathrm{mg} / \mathrm{m}^{3}$ in some instances), that is, enhanced coastal productivity fuelled by the higher availability of nutrients (Figures 4(c) and 4(d)). There is a general trend of lower nutrient and Chl- $a$ values during the winter (June-Aug) along the SHBML and higher nutrient and Chl- $a$ during the upwelling season (Figures 4 and 5). However, similar to the observations made for temperature, the annual cycles are disrupted by numerous events, during which nutrient and Chl- $a$ levels are contrary to this generalized view of surface ocean nutrient dynamics. The result is variability that exhibits very poor seasonality (Figure 5). The relationship between the UI and the nutrient parameters dissolved $\mathrm{NO}_{3}{ }^{-}, \mathrm{PO}_{4}{ }^{3-}$, and $\mathrm{Si}$ is very weak at the near surface but is slightly better expressed at $20 \mathrm{~m}$ depth, where the relationship with the UI is positive, as expected in a upwelling area (Table 2, Figures 4(a) and 4(b)). Of the three nutrient proxies, $\mathrm{PO}_{4}{ }^{3-}$ shows the strongest relationship with the UI (Table 2). Chl-a levels exhibit a weak but positive relationship with the UI at both sampling depths and all stations (Table 2, Figures 4(c) and 4(d)).
Nutrient and Chl- $a$ variability associated with the warm water events that disrupt the seasonal temperature profile, and the fresher water events that disrupt the seasonal salinity profile, bear further scrutiny. The anomalous warm water events observed at station 1 in the summer (Dec.-Feb.) of 2005, the summer (Dec.-Feb.) of 2006, late spring (Nov.) in 2007, and in spring (Sept.-Nov.) in 2009 are all characterized by much lower than usual surface nutrient levels $(0.17$ to $2.41 \mu \mathrm{mol} / \mathrm{L}$ for $\mathrm{NO}_{3}{ }^{-}$and 0.26 to $1.21 \mu \mathrm{mol} / \mathrm{L}$ for $\mathrm{PO}_{4}{ }^{3-}$ ). The most pronounced of these, during the summer (DecFeb) of 2005 was also associated with very high Chl-a levels $\left(33.4 \mathrm{mg} / \mathrm{m}^{3}\right)$ and temperature-salinity properties $(T=$ $17.38^{\circ} \mathrm{C}$ and $\left.S=34.79 \mathrm{PSU}\right)$ that rule out the intrusion of an offshore warm-nutrient-depleted water mass (Figure 2) as an explanation for this event. The high temperature suggests thermal heating as the cause of the elevated temperature, and the low nutrient and high Chl-a levels suggest the existence of an algal bloom, caused by the existence of stratified conditions conducive to enhanced phytoplankton productivity. The combined temperature-salinity-nutrient-Chla properties that characterize the other warm water events that are evident in the temperature record (Figure 3(a)) are more ambiguous. Although conditions similar to those which appear to have caused the summer (Dec-Feb) 2005 warm event cannot be ruled out, such conditions also cannot be confirmed with the data available. 


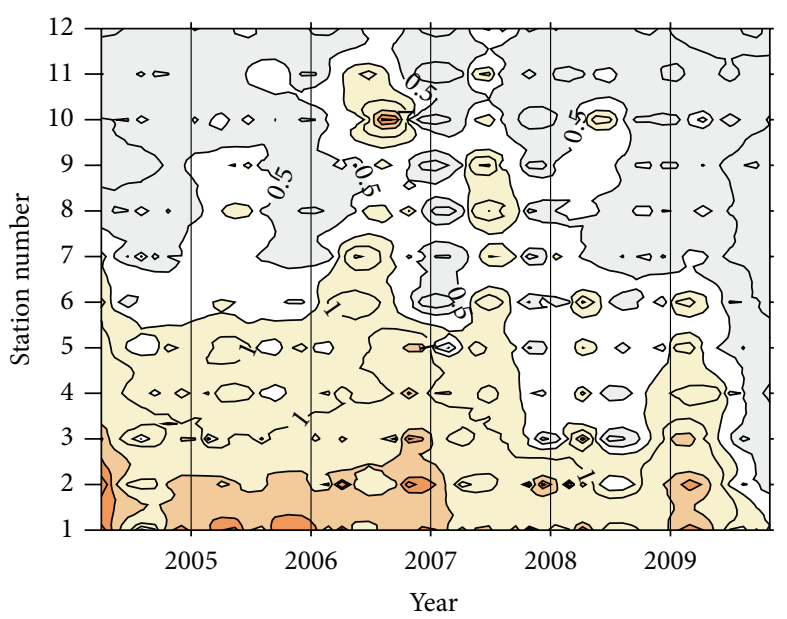

(a) Dissolved phosphate $(\mu \mathrm{mol} / \mathrm{L})$ near surface

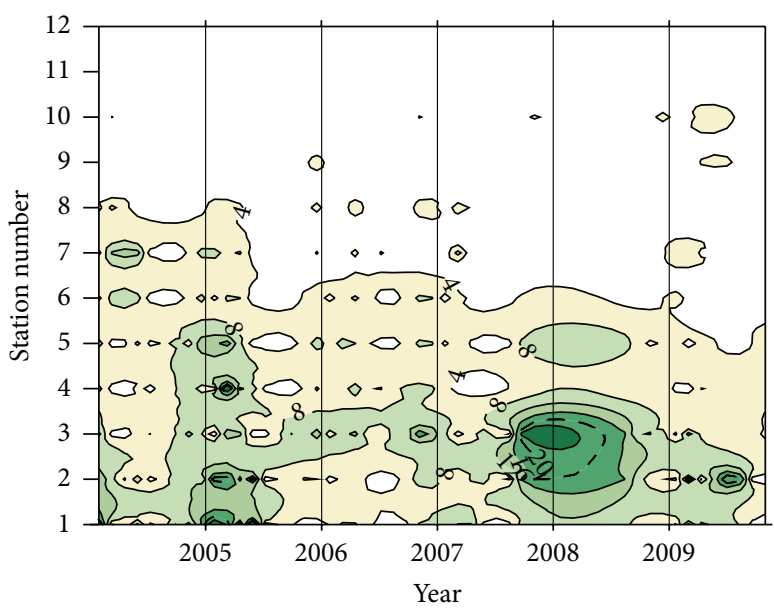

(c) Chl- $a\left(\mathrm{mg} / \mathrm{m}^{3}\right)$ near surface

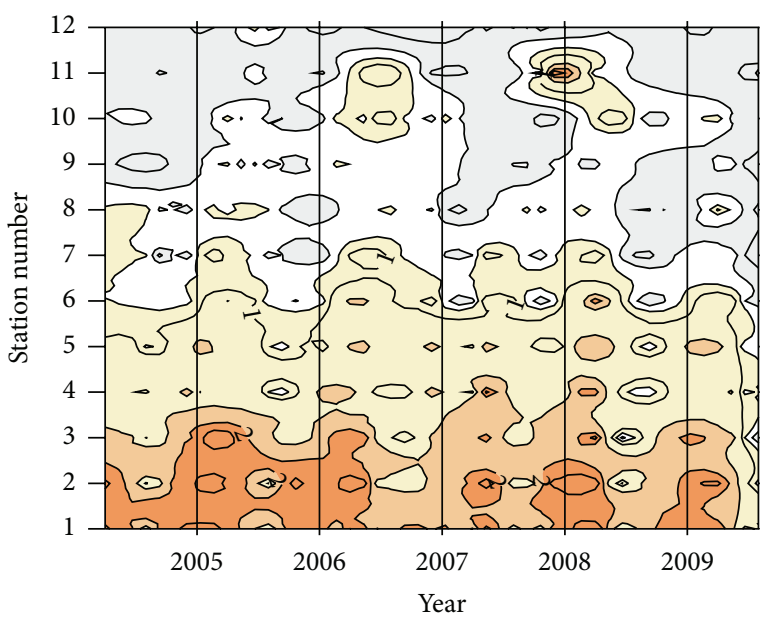

(b) Dissolved phosphate $(\mu \mathrm{mol} / \mathrm{L})$ at $20 \mathrm{~m}$ depth

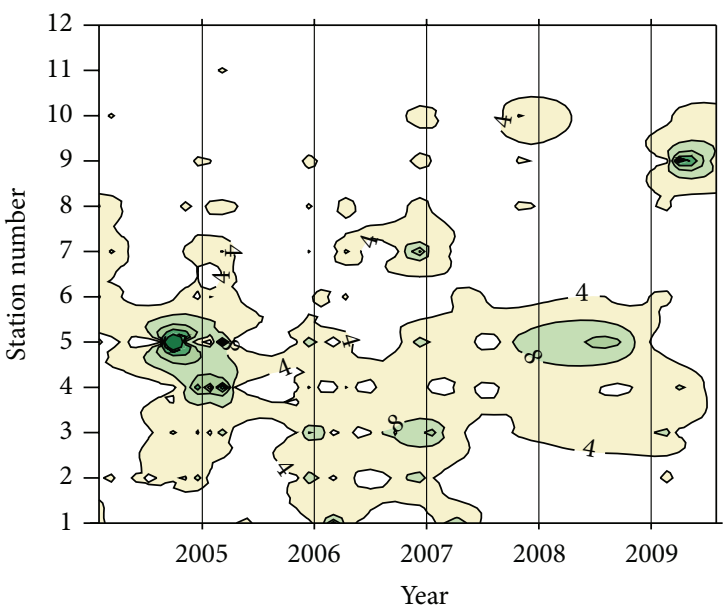

(d) Chl- $a\left(\mathrm{mg} / \mathrm{m}^{3}\right)$ at $20 \mathrm{~m}$ depth

FIGURE 4: Inshore-offshore near-surface ( $\mathrm{a}$ and $\mathrm{c}$ ) and $20 \mathrm{~m}$ depth ( $\mathrm{b}$ and $\mathrm{d}$ ) variability over time for dissolved phosphate (a and b) and Chl- $a$ ( $\mathrm{c}$ and $\mathrm{d})$. Dissolved phosphate $(\mu \mathrm{mol} / \mathrm{L})$ and Chl $-a\left(\mathrm{mg} / \mathrm{m}^{3}\right)$ values are indicated as labels on respective isobars. The dissolved phosphate ranged between $<0.5 \mu \mathrm{mol} / \mathrm{L}$ (grey) and $>2 \mu \mathrm{mol} / \mathrm{L}$ (dark orange). Chl- $a$ ranged between $<4 \mathrm{mg} / \mathrm{m}^{3}$ (white) and $>20 \mathrm{mg} / \mathrm{m}^{3}$ (dark green).

The most pronounced low-salinity event observed occurred in the winter (June-August) of 2007 (Figures 2(c) and $3(\mathrm{~b})$ ). The temperature, nutrient, and Chl- $a$ levels associated with this event, however, are not unusually high or low, with the exception of lower than usual dissolved Si levels $(5.42 \mu \mathrm{mol} / \mathrm{L})$. An explanation for the origin of the lowsalinity water observed in early spring (September) in 2008 and later winter (August) 2009 is also difficult to extract from the available data. Although continental run-off from winter (June-August) rainfall over the adjacent landmass cannot be ruled out as a contributing factor, there is nothing in the data available to substantiate such a hypothesis at this stage.

3.3. Relationship between the UI and Vertical Temperature and Nutrient Gradients. Evaluation of variability in the upper ocean temperature gradient (shown for station 1 in Figure 6), in comparison with seasonal variability in the upwelling index, shows that the temperature gradient exhibits better defined seasonal variability than surface ocean temperature. Along the SHBML the water column is more stratified during spring (Sept.-Nov.) and summer (Dec.-Feb.) than during the winter (June-August). Generally speaking, surface temperatures and surface-deep water temperature gradients are determined by a balance between surface heating and windinduced vertical mixing. Along the SHBML the net surface heat flux is positive and is increasing during the spring-summer upwelling season. The water column stabilization and stratification that result from this counter the tendency for vertical mixing induced by upwelling-favorable winds during the spring-summer season, during most years (Figure 6). During the winter (June-August) the water column is better mixed, despite the prevailing downwelling-favorable winds during this season.

The balance between surface heating and vertical mixing is clearly in favor of surface heating in St. Helena Bay. This has implications not only for the application of remote sensing 


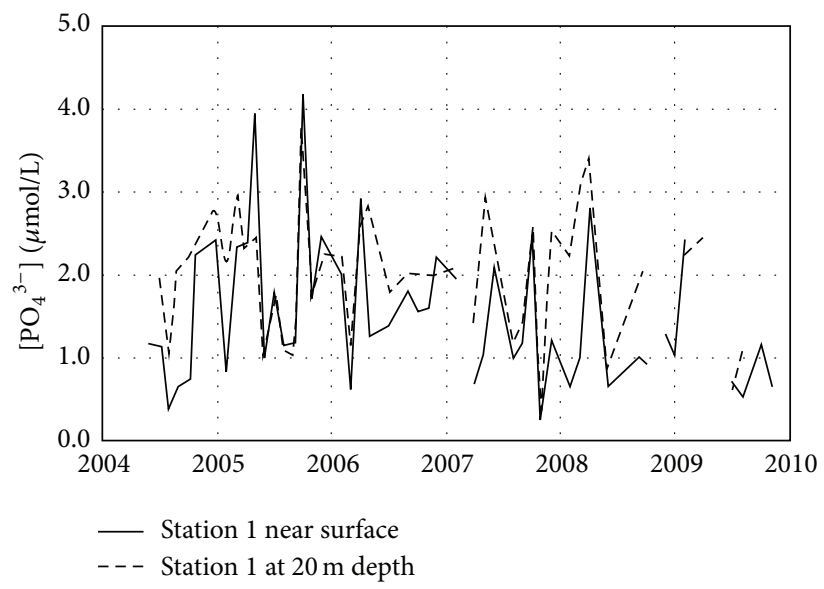

(a)

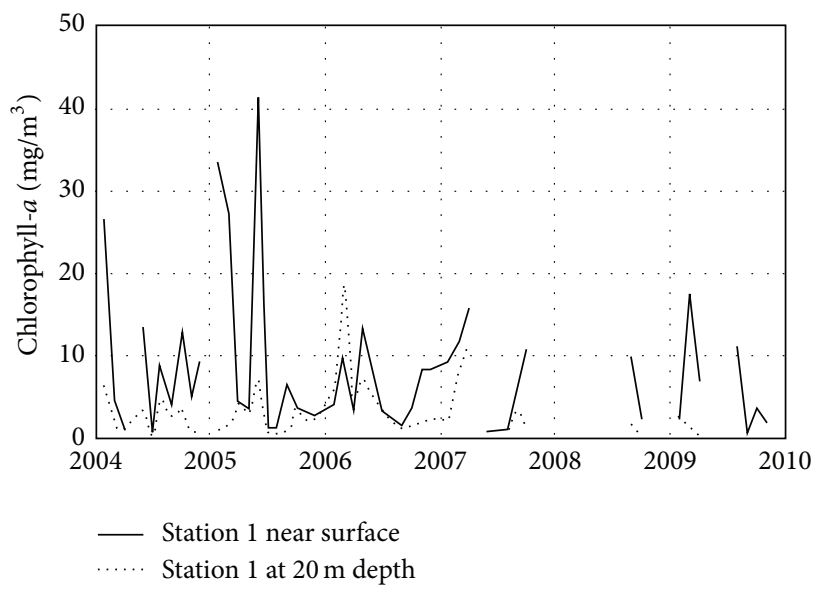

(b)

FIGURE 5: Temporal changes in (a) dissolved phosphate $\left(\mathrm{PO}_{4}{ }^{3-}\right)$ and (b) Chl- $a$ at station 1 near surface and at $20 \mathrm{~m}$ depth.

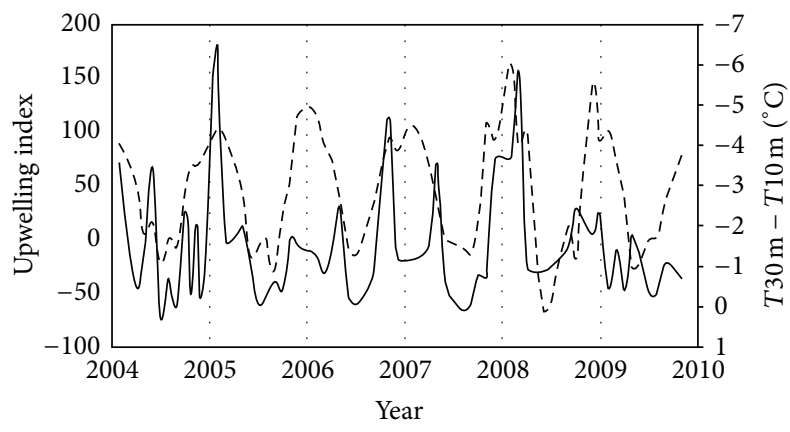

FIgURE 6: Variability in the upwelling index (dashed line) versus the temperature difference between 30 and $10 \mathrm{~m}$ depths (solid line), at station 1, for the time period 2004 to 2009.

methods to track upwelling events, but also for biological processes and spatial and temporal variability therein. Planktonic organisms tend to be distributed throughout the water column when it is well mixed, which is winter-time along the SHBML. When the water column is stratified, that is, spring-summer along the SHBML, it favors the development of algal blooms. Also, this concentration of food particles in a stratified water column is believed to be advantageous to the growth of larval fish [20].

\section{Conclusions}

It is clear from the results that all physical and chemical parameters exhibit pronounced across-shelf variability along the SHBML in the surface ocean, but very poor seasonality and no significant relationship with the calculated upwelling index. This does not mean that the observed weak relationships do not provide valuable insight into upwelling processes in St. Helena Bay. It does mean, however, that the weak relationship between wind-induced upwelling and inner shelf temperature cast doubt on the usefulness of satellite observations in detecting upwelling events in this part of the southern Benguela Upwelling system, as reflected either in decreased sea-surface temperatures or in surface Chl- $a$ distributions. It also poses a problem for using moored offshore buoys as detectors of upwelling events. The tabulated regression coefficients for the UI and temperature (Table 2) suggest that 
station 2 (located approximately $7 \mathrm{~km}$ offshore) would be the best location to moor such a buoy and that the focus should be on temperature variability at $20 \mathrm{~m}$ depth rather than at the surface.

The observation that surface heating and water column stratification resulting from it outbalance wind-induced vertical mixing during the upwelling season in St. Helena Bay has important implications. First of all, it explains the poor correlation between sea surface temperature variability and the upwelling index, as well as the poor correlation between the UI and nutrient parameters. Secondly, it implies that remote sensing techniques will be poor indicators of upwellingrelated variability in surface temperature and chlorophyll distributions in St. Helena Bay. It is also a critical observation in regard to understanding the factors that contribute to harmful algal blooms and the increasing incidence of such events.

\section{Conflict of Interests}

The authors declare that there is no conflict of interests regarding the publication of this paper.

\section{Acknowledgments}

The authors would like to thank the Branch: Oceans and Coasts, Department of Environmental Affairs (DEA) for making use of the excellent laboratory facilities and the support of funding in this study. This study could not have been done without the data collection efforts of S. Jones, F. Frantz, G. Kiviets, G. Tutt, E. Wright and M. Worship during this 6year period. Special thanks to CM Illert for assistance with data management and archiving. The officers and crew of the research vessels Africana, Algoa and Ellen Khuzwayo are thanked for their professional manner and patience despite bad weather. The work presented stems from the MTech research project of the first author.

\section{References}

[1] A. M. B. de Decker, Notes on an Oxygen-depleted Subsurface Current Off the West Coast of South Africa, vol. 84, Division of Sea Fisheries Investigational Report, 1970.

[2] S. E. Calvert and N. J. Price, "Upwelling and nutrient regeneration in the Benguela Current, October, 1968," Deep-Sea Research and Oceanographic Abstracts, vol. 18, no. 5, pp. 505-523, 1971.

[3] W. R. H. Andrews and L. Hutchings, "Upwelling in the Southern Benguela Current," Progress in Oceanography, vol. 9, no. 1, pp. 18, 1980.

[4] L. V. Shannon and G. Nelson, "The Benguela: large scale features and processes and system variability," in The South AtlanticPresent and Past Circulation, pp. 163-210, Springer, Berlin, Germany, 1996.

[5] R. Kudela, G. Pitcher, T. Probyn, F. Figueiras, T. Moita, and V. Trainer, "Harmful algal blooms in coastal upwelling systems," Oceanography, vol. 18, no. 2, pp. 184-197, 2005.

[6] L. Hutchings, A. Jarre, T. Lamont, M. van den Berg, and S. P. Kirkman, "St Helena Bay (southern Benguela) then and now: muted climate signals, large human impact," African Journal of Marine Science, vol. 34, no. 4, pp. 559-583, 2012.
[7] R. G. Barlow, "Phytoplankton ecology in the Southern Benguela current. I. Biochemical composition," Journal of Experimental Marine Biology and Ecology, vol. 63, no. 3, pp. 209-227, 1982.

[8] H. N. Waldron, Influences on the hydrology of the Cape Columbine/St Helena Bay region [M.S. thesis], Oceanography Department, University of Cape Town, 1985.

[9] G. B. Brundrit, "The dynamic control of biological activity in the southern Benguela upwelling region," in Marine Interfaces Ecohydro-Dynamics, J. C. J. Nihoul, Ed., Elsevier Oceanography Series 42, pp. 95-104, Elsevier, Amsterdam, The Netherlands, 1986.

[10] L. Hutchings, D. A. Armstrong, and B. A. Mitchell-Innes, "The frontal zone in the southern Benguela Current," in Marine Interfaces Ecohydro-Dynamics, J. C. J. Nihoul, Ed., vol. 42 of Elsevier Oceanography Series, pp. 67-94, Amsterdam, The Netherlands, 1985.

[11] M. J. Armstrong, A. Berruti, and J. Colclough, "Pilchard distributions in South African waters, 1983-1985," South African Journal of Marine Science, vol. 5, no. 1, pp. 871-886, 1987.

[12] R. V. Dingle and G. Nelson, "Sea-bottom temperature, salinity and dissolved oxygen on the continental margin off southwestern Africa," South African Journal of Marine Science, vol. 13, pp. 33-49, 1993.

[13] F. Santos, M. Gomez-Gesteira, M. deCastro, and I. Alvarez, "Differences in coastal and oceanic SST trends due to the strengthening of coastal upwelling along the Benguela current system," Continental Shelf Research, vol. 34, pp. 79-86, 2012.

[14] J. M. Fourie and A. G. Steer, "A survey of water quality of the great berg river (1963 to 1970) October 1971," The Provincial Administration of the Cape of Good Hope, p. 80, 1971.

[15] S. de Villiers, "The deteriorating nutrient status of the Berg River, South Africa," Water SA, vol. 33, no. 5, pp. 659-664, 2007.

[16] E. Kalnay, M. Kanamitsu, R. Kistler et al., "The NCEP/NCAR 40-year reanalysis project," Bulletin of the American Meteorological Society, vol. 77, no. 3, pp. 437-471, 1996.

[17] K. Grasshoff, E. Ehrhardt, and K. Kremling, Methods of Seawater Analysis, Verlag Chemie, Weinheim, Germany, 2nd edition, 1983.

[18] T. R. Parsons, Y. Maita, and C. M. Lalli, A Manual of Chemical and Biological Methods for Seawater Analysis, Pergamon Press, Oxford, UK, 1984.

[19] N. A. Welschmeyer, "Fluorometric analysis of chlorophyll $a$ in the presence of chlorophyll b and pheopigments," Limnology and Oceanography, vol. 39, no. 8, pp. 1985-1992, 1994.

[20] L. J. Buckley and R. G. Lough, "Recent growth, biochemical composition, and prey field of larval haddock (Melanogrammus aeglefinus) and Atlantic cod (Gadus morhua) on Georges Bank," Canadian Journal of Fisheries and Aquatic Sciences, vol. 44, no. 1, pp. 14-25, 1987. 

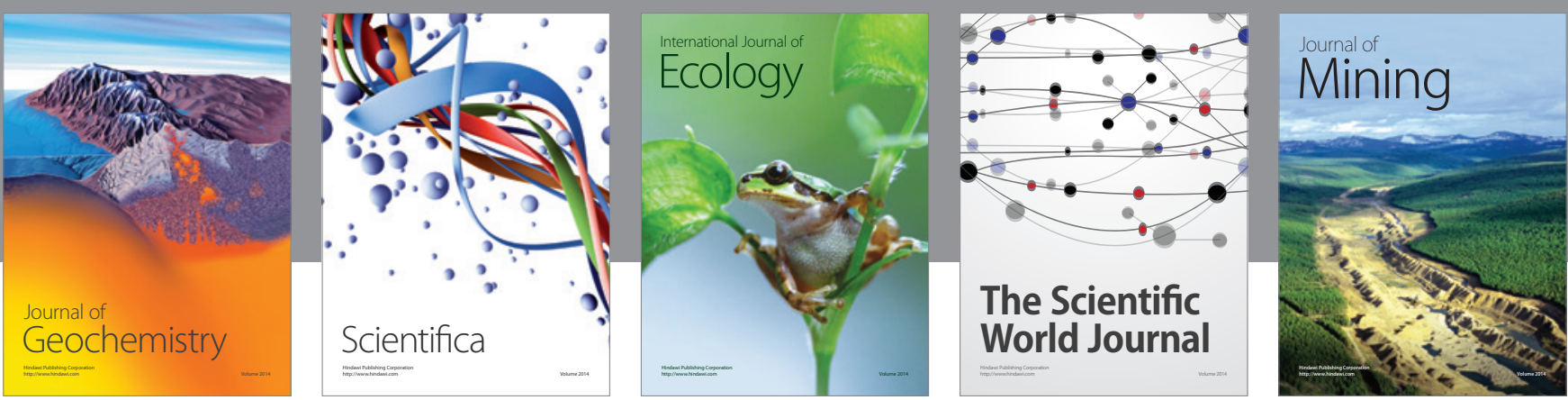

The Scientific World Journal
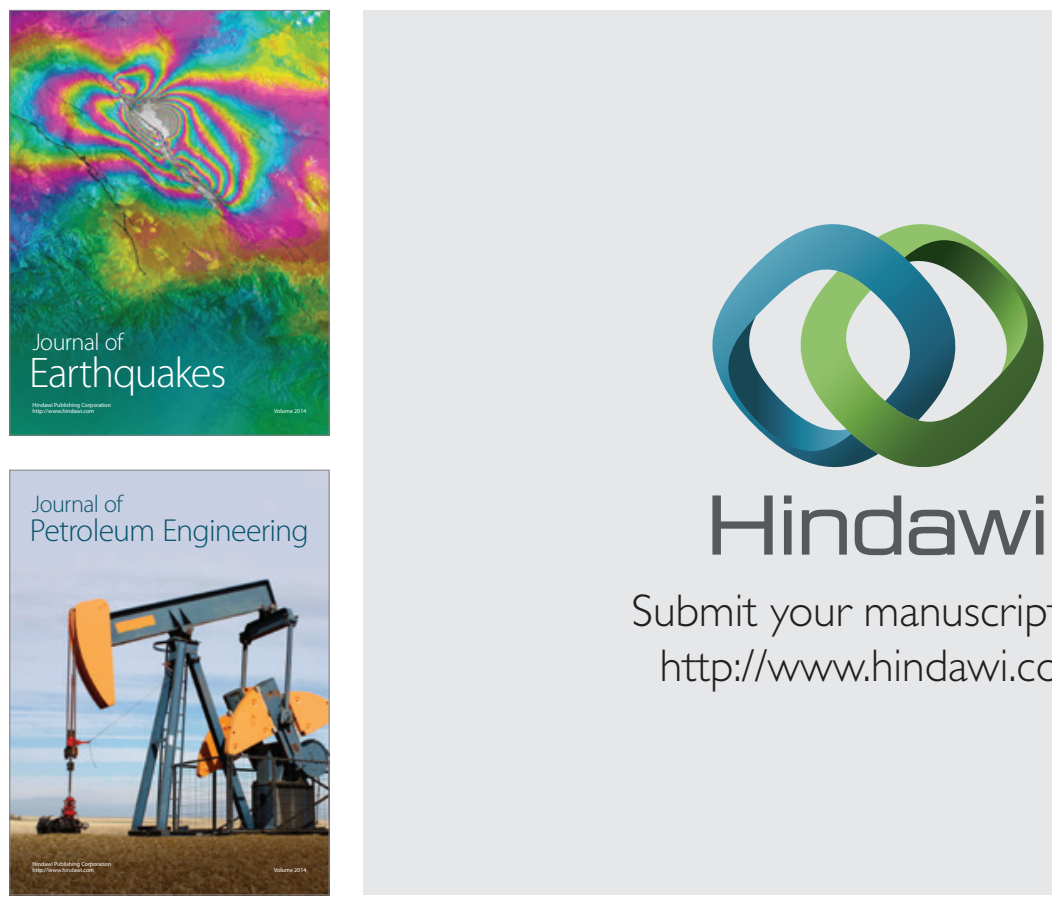

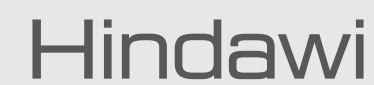

Submit your manuscripts at

http://www.hindawi.com
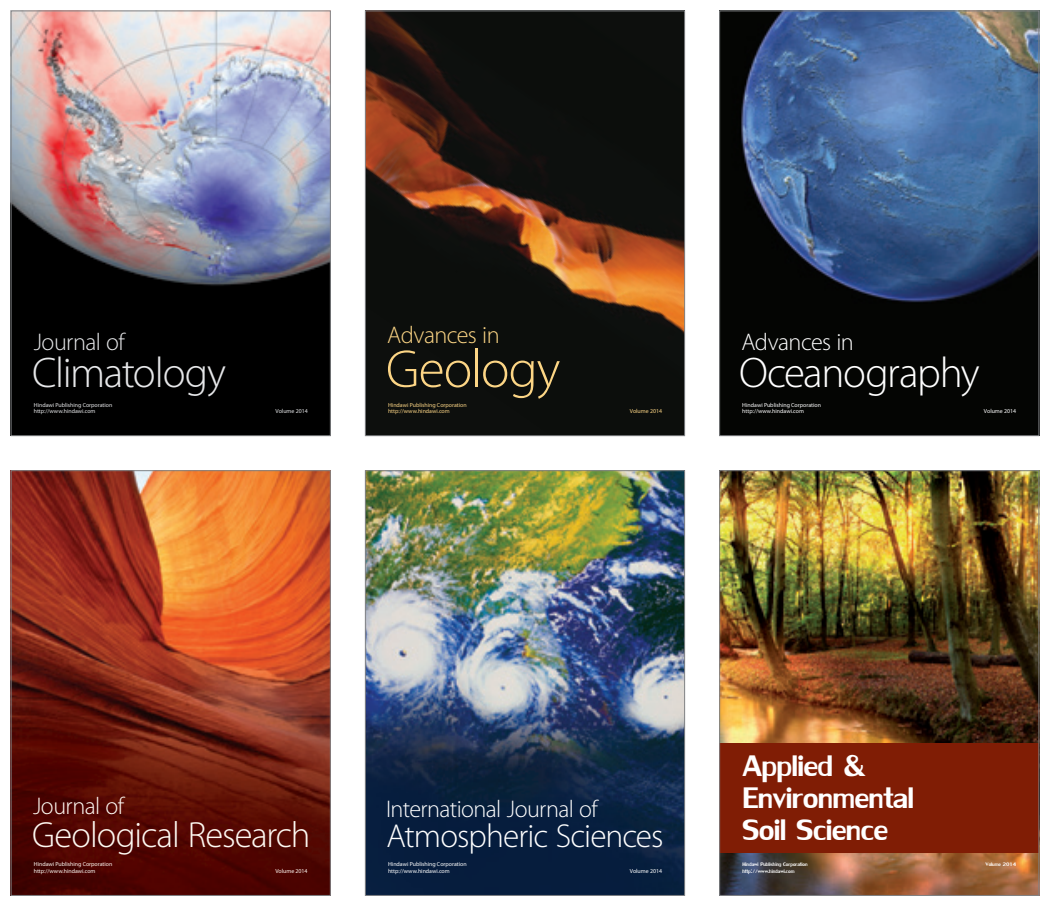
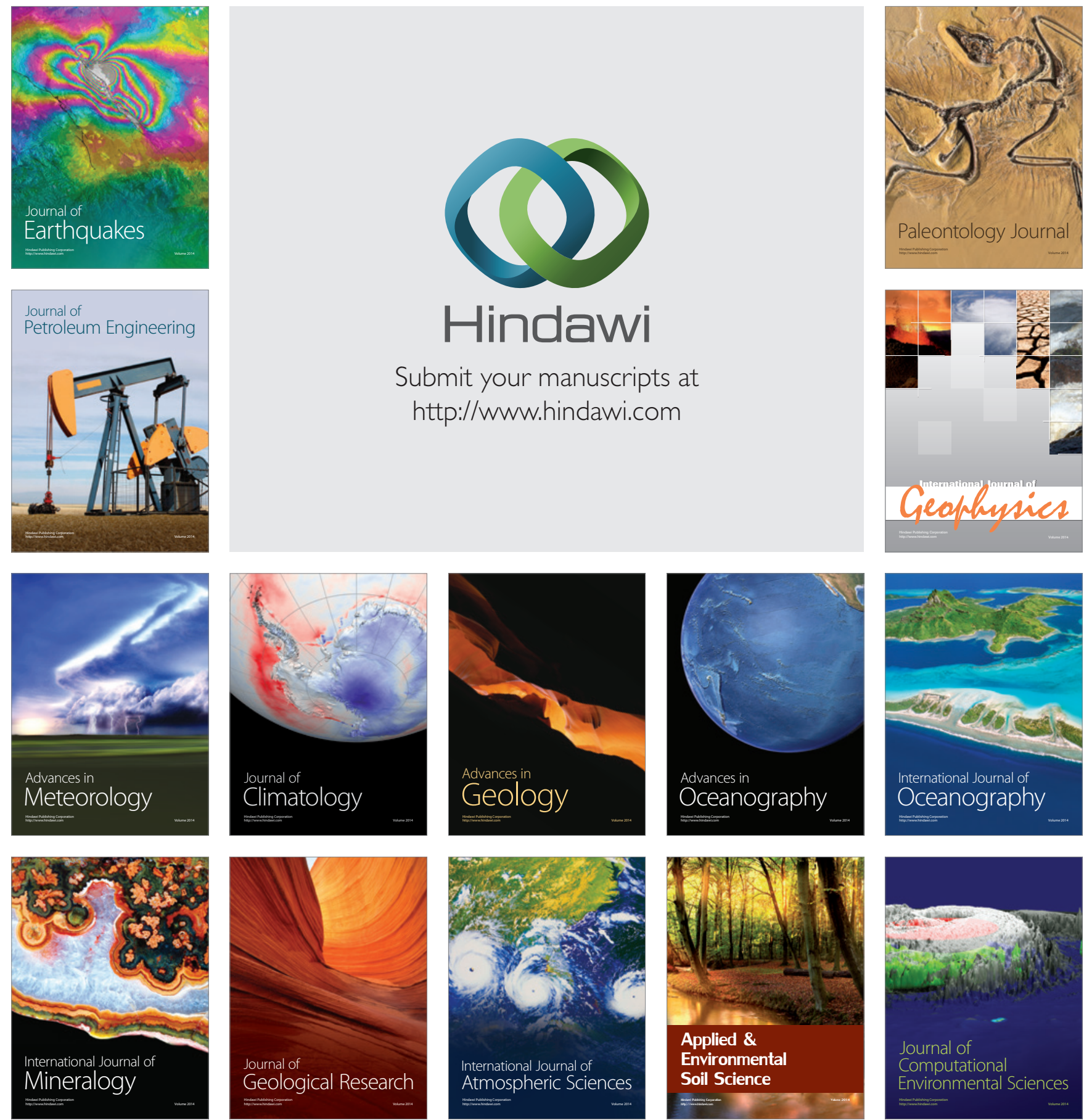